\title{
CXCL16 induces angiogenesis in autocrine signaling pathway involving hypoxia-inducible factor $1 \alpha$ in human umbilical vein endothelial cells
}

\author{
XIAOWEN YU ${ }^{1 *}$, RENPING ZHAO ${ }^{2 *}$, SENSEN LIN ${ }^{3}$, XIANSHU BAI ${ }^{4}$, \\ LUYONG ZHANG $^{3}$, SHENGTAO YUAN ${ }^{1}$ and LI SUN ${ }^{3}$
}

\begin{abstract}
${ }^{1}$ Jiangsu Center for Pharmacodynamics Research and Evaluation, China Pharmaceutical University, Nanjing, Jiangsu 210009, P.R. China; ${ }^{2}$ Department of Biophysics, University of Saarland, D-66421 Homburg, Germany;

${ }^{3}$ Jiangsu Center for Drug Screening, China Pharmaceutical University, Nanjing, Jiangsu 210009, P.R. China;

${ }^{4}$ Department of Molecular Physiology, University of Saarland, D-66421 Homburg, Germany
\end{abstract}

Received July 3, 2015; Accepted August 13, 2015

DOI: $10.3892 /$ or.2015.4520

\begin{abstract}
Chemokine (C-X-C motif) ligand 16 (CXCL16) is a new angiogenic factor inducing angiogenesis via extracellular signal-regulated kinases pathway. To further understand the molecular mechanism underlying CXCL16-induced angiogenesis, we explored involvement of other relevant pathways in CXCL16-induced angiogenesis. In the present study, we investigated the mechanisms underlying CXCL16induced angiogenesis in human umbilical vein endothelial cells (HUVECs). CXCL16 promoted HUVEC proliferation, tube formation and migration. Enzyme-linked immunosorbent assay revealed that CXCL16 induced vascular endothelial growth factor secretion from HUVECs. Western blot analysis showed that CXCL16 increased the level of hypoxia-inducible factor $1 \alpha$, p-extracellular signal-regulated kinases (ERK), p-p38 and p-Akt dose- and time-dependently. ERK-, p38- and Akt-selective inhibitors significantly suppressed HUVEC proliferation, migration, tube formation and hypoxiainducible factor $1 \alpha$ (HIF-1 $\alpha$ ) expression induced by CXCL16. Furthermore, CXCL16 peptides induced CXCL16 secretion via ERK, p38 and Akt pathways, which was suppressed by HIF-1 $\alpha$-selective inhibitor PX12. Our data suggest that
\end{abstract}

Correspondence to: Professor Shengtao Yuan, Jiangsu Center for Pharmacodynamics Research and Evaluation, China Pharmaceutical University, 24 Tongjiaxiang, Nanjing, Jiangsu 210009, P.R. China E-mail: cpuyuanst@163.com

Dr Li Sun, Jiangsu Center for Drug Screening, China Pharmaceutical University, 24 Tongjiaxiang, Nanjing, Jiangsu 210009, P.R. China

E-mail: cpusunli@126.com

*Contributed equally

Key words: CXCL16, autocrine, angiogenesis, hypoxia-inducible factor $1 \alpha$, Akt pathway, ERK pathway, p38 pathway
CXCL16 induces angiogenesis in autocrine manner via ERK, Akt, p38 pathways and HIF-1 $\alpha$ modulation.

\section{Introduction}

Chemokine (C-X-C motif) ligand 16 (CXCL16) is a member of CXC chemokine family, initially identified in dendritic cells in $\mathrm{T}$ cell zone and cells in the splenic red pulp (1). Later, the expression of CXCL16 in macrophages $(2,3)$, dendritic (4), liver sinusoidal endothelial (5) and cancer cells (6-8) was observed. There are two forms of CXCL16: membrane-bound CXCL16 inducing firm adhesion in chemokine (C-X-C motif) receptor 6 (CXCR6) expressing cells (9), and soluble CXCL16 inducing migration in CXCR6 expressing cells $(10,11)$. CXCL16 is involved in progress of many diseases (12-14), including cancer $(6,7)$. For instance, higher expression of CXCL16 reduced the overall survival of cancer patients (6); CXCR6 is involved in cancer the cell proliferation and invasion in vitro (15). Our previous research showed that CXCR6 contributed to breast cancer cell migration via the regulation of hypoxia-inducible factor $1 \alpha$ (HIF-1 $\alpha$ ) under hypoxia (16).

The effect of CXCL16 in cancer cell is well defined, while the effect of CXCL16 on angiogenesis is rarely studied. Previous research has reported that CXCL16 promotes human umbilical vein endothelial cell (HUVEC) proliferation, chemotaxis, and tube formation by activating ERK pathway in vitro (17). Whereas, the role of other pathways and their involvement in CXCL16-induced angiogenesis is not clear. It has been observed that CXCL16 improves the human aortic smooth muscle cells proliferation and adhesion by activating the PI3K/Akt pathway (18) whereas the binding of dextran sulfate sodium to CXCL16 activates the p38 pathway in murine peritoneal macrophages (19). Moreover, the activation of $\mathrm{p} 38$ and Akt pathways induces angiogenesis (20-22).

In the present study, we investigated the molecular mechanisms underlying CXCL16-induced angiogenesis. Our results revealed that CXCL16 induced angiogenesis and HIF-1 $\alpha$ expression by activating the ERK, p38 and Akt pathways in HUVECs. Furthermore, we found that CXCL16 increased 
VEGF and CXCL16 secretion by modulating HIF-1 $\alpha$ in HUVECs.

\section{Materials and methods}

Cell culture. HUVECs were cultured in complete medium consisted of M199 medium, 20\% FBS, $50 \mathrm{ng} / \mathrm{ml}$ endothelial cell growth supplement (ECGS) (both from Sigma) and $100 \mathrm{ng} / \mathrm{ml}$ heparin. Cells were incubated in humidified atmosphere with $5 \% \mathrm{CO}_{2}$ at $37^{\circ} \mathrm{C}$. HUVECs at the 6-9th passage were used for experiments.

Cell proliferation assay. HUVECs were seeded into a 24-well plate in complete medium and cultured overnight. After the replacement of medium with M199 supplemented with $1 \%$ FBS and $100 \mathrm{ng} / \mathrm{ml}$ heparin, HUVECs were pre-treated with $2.5 \mu \mathrm{M}$ FR180204 (ERK-selective inhibitor), $5 \mu \mathrm{M}$ SB202190 (p38 MAP kinase-selective inhibitor), $5 \mu \mathrm{M}$ LY294002 (selective inhibitor of phosphatidylinositol 3-kinase) or $10 \mu \mathrm{M} \mathrm{PX12}$ (HIF-1 $\alpha$-selective inhibitor) (all from Tocris Bioscience) for $1 \mathrm{~h}$. Then cells were exposed to $0,1,10$ and $100 \mathrm{ng} / \mathrm{ml} \mathrm{CXCL16}$ polypeptide (PeproTech) for $48 \mathrm{~h}$. Cells were then counted in five randomly selected fields per group under a microscope.

CXCL16 was dissolved in phosphate-buffered saline (PBS); FR180204, SB202190, LY294002 and PX12 were dissolved in dimethylsulfoxide (DMSO).

Cell migration assay. Transwell chamber migration system with polycarbonate membranes $(8.0-\mu \mathrm{M}$ pore size; Corning) was used for cell migration assay (23). The medium used in the migration assay consisted of M199, $1 \%$ FBS and $100 \mathrm{ng} / \mathrm{ml}$ heparin. HUVECs $\left(1 \times 10^{4}\right.$ cells $\left./ \mathrm{ml}\right)$ were seeded into the upper chamber with $2.5 \mu \mathrm{M}$ FR180204, $5 \mu \mathrm{M} \mathrm{SB} 202190,5 \mu \mathrm{M}$ LY294002 or $10 \mu \mathrm{M}$ PX12. Medium with CXCL16 (100 ng/ml) and FBS (10\%) was added into the lower chamber. HUVECs $\left(1 \times 10^{4}\right.$ cells $\left./ \mathrm{ml}\right)$ were seeded into the upper chamber along with various concentrations of CXCL16 $(1,10$ or $100 \mathrm{ng} / \mathrm{ml})$ added into the lower chamber. The cell migration system was incubated at $37^{\circ} \mathrm{C}$ for $6 \mathrm{~h}$. Cells were fixed with $4 \%$ paraformaldehyde, stained with $0.2 \%$ cresyl violet solution and counted in five randomly selected fields.

Tube formation assay. Tube formation assay was performed as previously described (23), 96-well plates were coated with $50 \mu \mathrm{l} /$ well growth factor reducing Matrigel (Becton, Dickinson and Company) and incubated at $37^{\circ} \mathrm{C}$ for $2 \mathrm{~h}$. HUVECs $\left(1 \times 10^{4}\right.$ cells/well) were incubated with CXCL16 $(0,1,10$ or $100 \mathrm{ng} / \mathrm{ml})$ at $37^{\circ} \mathrm{C}$ for $12 \mathrm{~h}$. Or, HUVECs $\left(1 \times 10^{4}\right.$ cells/well $)$ were incubated with $2.5 \mu \mathrm{M}$ FR180204, $5 \mu \mathrm{M}$ SB202190 or $5 \mu \mathrm{M}$ LY294002 in the presence of CXCL16 $(100 \mathrm{ng} / \mathrm{ml})$ for $24 \mathrm{~h}$. Or, HUVECs $\left(1 \times 10^{4}\right.$ cells/well) were treated with or without $10^{-5} \mathrm{M}$ topotecan in the presence of CXCL16 (1 'or $100 \mathrm{ng} / \mathrm{ml}$ ) for $12 \mathrm{~h}$. Tubes were counted in five randomly selected fields per group under a microscope.

Western blotting. HUVECs were treated with $100 \mathrm{ng} / \mathrm{ml}$ of CXCL16 for 0, 10, 20, 30, 40 and $50 \mathrm{~min}$ in a time-dependent study and with different concentrations of CXCL16 $(0,1$, 10 and $100 \mathrm{ng} / \mathrm{ml}$ ) for $30 \mathrm{~min}$ in a dose-dependent study; or with $100 \mathrm{ng} / \mathrm{ml}$ of CXCL16 for $0,3,6,9$, and $12 \mathrm{~h}$; or with
$100 \mathrm{ng} / \mathrm{ml}$ of CXCL16 in the presence of DMSO, $2.5 \mu \mathrm{M}$ FR180204, $5 \mu \mathrm{M}$ SB202190 or $5 \mu \mathrm{M}$ LY294002, respectively. Conditioned medium was collected and concentrated with Amicon Ultra-15 (with Ultracel-10; Millipore). Cells were washed with ice-cold PBS and then lysed with RIPA buffer (Beyotime). Total protein concentration was evaluated with the BCA protein assay reagent kit (Pierce, Rockford, IL, USA). Denatured samples ( $40 \mu \mathrm{g} /$ lane) were separated by 10-15\% sodium dodecyl sulfate-polyacrylamide gel electrophoresis (SDS-PAGE). Transferred membranes were probed with murine anti-human antibodies: anti-CXCL16 antibody (R\&D Systems), anti-HIF-1 $\alpha$ antibody (Sigma), anti-p-ERK1/2 antibody, anti-p-Akt antibody, anti-p-p38 MAPK antibody, anti-ERK1/2 antibody, anti-Akt antibody, anti-p38 antibody (all from Cell Signaling Technology) and anti-actin antibody (Sigma). Horseradish peroxidase (HRP)-linked anti-rabbit IgG (Cell Signaling Technology) or HRP-linked anti-mouse IgG (Sigma) was used as the secondary antibody. Immunoreactive proteins on the membrane were visualized by enhanced chemiluminescence western blotting detection reagents (Millipore, USA).

Real-time quantitative PCR. HUVECs were pre-treated with or without $10 \mu \mathrm{M}$ PX12 for $1 \mathrm{~h}$, followed by the treatment of $100 \mathrm{ng} / \mathrm{ml}$ of CXCL16 for 3 or $6 \mathrm{~h}$; or followed by incubation under normoxia or hypoxia for $6 \mathrm{~h}$. Total cell RNA was isolated with TRIzol ${ }^{\circledR}$ reagent (Invitrogen). Total RNA $(2 \mu \mathrm{g})$ was used for first-strand cDNA synthesis with RevertAid First Strand cDNA Synthesis kit (Fermentas). Primers for RT-PCR sequences were as follows: HIF-1 $\alpha$ forward, 5'-CTCACCCA ACGAAAAATTACAGAA-3' and HIF-1 $\alpha$ reverse, 5'-ATTGA GTGCAGGGTCAGCACTAC-3' (24); CXCL16 forward, 5'-GGCAGCGTCACTGGAAGTTGTTAT-3' and CXCL16 reverse, 5'-ACCGATGGTAAGCTCTCAGGTGTT-3'; $\beta$-actin forward, 5'-GAGCGGGAAATCGTGCGTGACATT-3' and $\beta$-actin reverse, 5'-GAAGGTAGTTTCGTGGATGCC-3' (25). $\mathrm{iQ}^{\mathrm{TM}}$ SYBR-Green Supermix (Bio-Rad Laboratories) was used as a fluorescent dye to detect the presence of double-stranded DNA. The amount of mRNA was normalized to an internal control $\beta$-actin mRNA. Relative mRNA levels were normalized to control.

VEGF enzyme-linked immunosorbent assay. HUVECs were exposed to $100 \mathrm{ng} / \mathrm{ml}$ of CXCL16 for $0,3,6,9,12,24$ and $30 \mathrm{~h}$. At each time point, conditioned medium were collected and concentrated at $8,000 \mathrm{rpm}$ at $4^{\circ} \mathrm{C}$ for $1 \mathrm{~min}$. The supernatant was collected and stored at $-70^{\circ} \mathrm{C}$. The enzyme-linked immunosorbent assay (ELISA) was performed according to the manufacturer's instruction for human VEGF.

Statistical analysis. All data represent at least three independent experiments and are expressed as mean \pm SEM. Student's $\mathrm{t}$-test was used for statistical analysis.

\section{Results}

Effects of CXCL16 on proliferation, migration and tube formation in HUVECs. To study the effect of CXCL16 on angiogenesis in vitro, HUVECs were treated with $1-100 \mathrm{ng} / \mathrm{ml}$ of CXCL16 for $48 \mathrm{~h}$ for the cell proliferation assay, $6 \mathrm{~h}$ formi- 


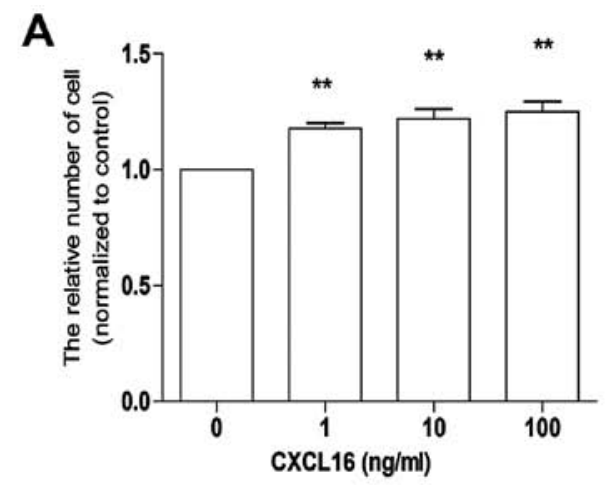

B

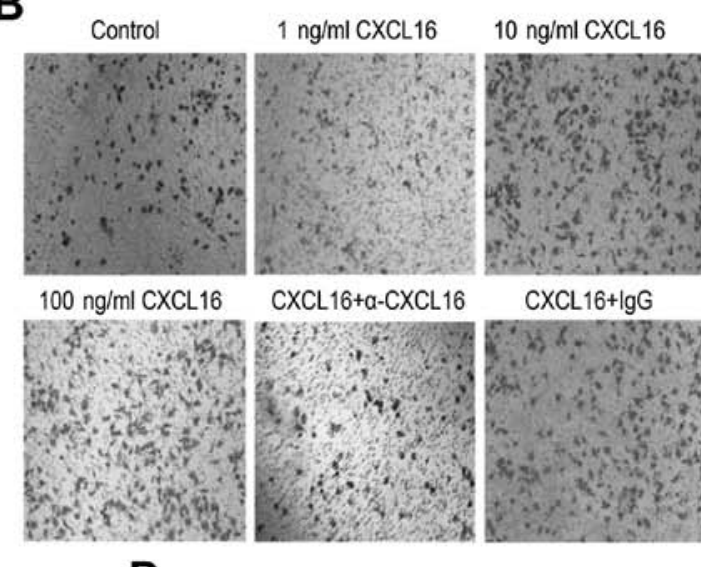

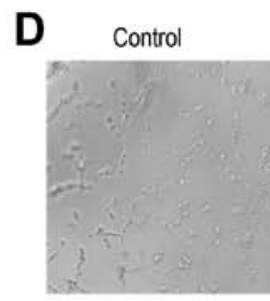

$10 \mathrm{ng} / \mathrm{ml}$

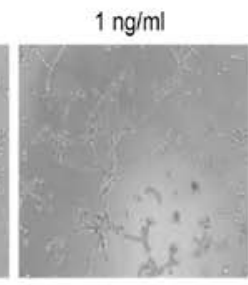

$100 \mathrm{ng} / \mathrm{ml}$

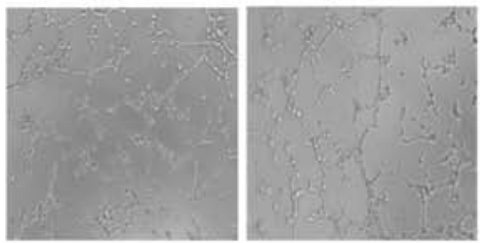

C

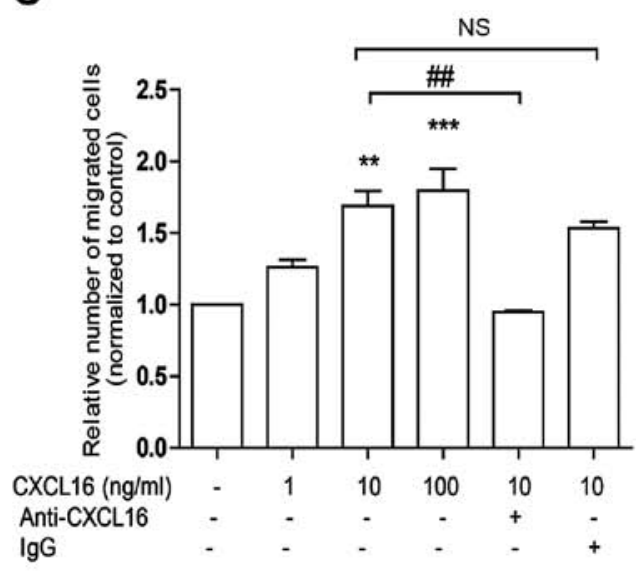

E

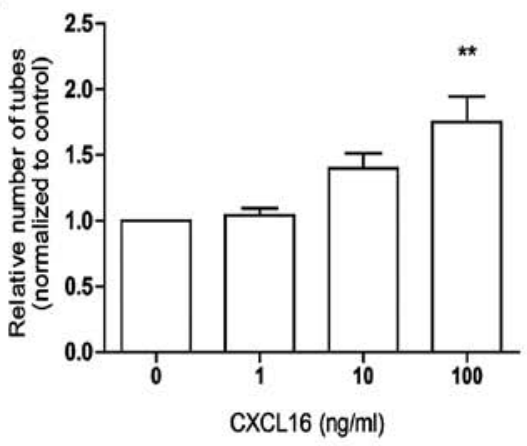

Figure 1. CXCL16 promotes angiogenesis in a dose-dependent manner. HUVECs were treated with different concentrations of CXCL16 (1, 10 and 100 ng/ml) for $48 \mathrm{~h}$ proliferation (A), $6 \mathrm{~h}$ migration (B and C), $6 \mathrm{~h}$ tube formation (D and E). Cells from five random fields per group were calculated under a microscope in $\mathrm{B}$ and D. ${ }^{* *} \mathrm{P}<0.01 ;{ }^{* * *} \mathrm{P}<0.001$, compared with control; ${ }^{\# \#} \mathrm{P}<0.01$.

gration assay and $12 \mathrm{~h}$ for tube formation assay. In line with previous research (17), our data showed that CXCL16 promoted HUVECs proliferation (Fig. 1A), migration (Fig. 1B and C) and tube formation (Fig. 1D and E) in a dose-dependent manner. Our data confirm that CXCL16 promotes HUVECs angiogenesis in vitro.

Effects of CXCL16 on the activation of ERK, p-38 and Akt pathways in HUVECs. In murine peritoneal macrophages and human aortic smooth muscle cells, CXCL16 activated ERK1/2, p38 and PI3K/Akt, respectively $(18,19)$. To determine whether CXCL16 could activate ERK1/2, p38 and Akt pathways in HUVECs, we treated HUVECs with CXCL16 (100 ng/ml) for $0,10,20,30,40$ and $50 \mathrm{~min}$. Western blot results revealed that the phosphorylation levels of ERK1/2, p38 and Akt were increased within $30 \mathrm{~min}$ and p-ERK1/2 and p-Akt were increased time-dependently (Fig. 2A).

After these findings, we studied the activation of ERK1/2, p38 and Akt pathways in HUVECs treated with different concentrations of CXCL16 $(0,1,10$ and $100 \mathrm{ng} / \mathrm{ml})$ for $30 \mathrm{~min}$. It was observed that p-ERK1/2 and p-Akt induced by CXCL16 were increased dose-dependently, whereas, p-p38 was increased in the presence of $100 \mathrm{ng} / \mathrm{ml}$ of CXCL16 (Fig. 2B).

To further elucidate the activation of ERK1/2, p38 and Akt pathways induced by CXCL16 in HUVECs against the time frame, we treated HUVECs with CXCL16 $(100 \mathrm{ng} / \mathrm{ml})$ for $0,3,6,9$ and $12 \mathrm{~h}$. Western blot results showed that all three pathways were activated within $3 \mathrm{~h}$ (Fig. 2C). However, the activation patterns of these pathways were different. ERK pathway was activated within $30 \mathrm{~min}$ (Fig. 2A) and lasted until 


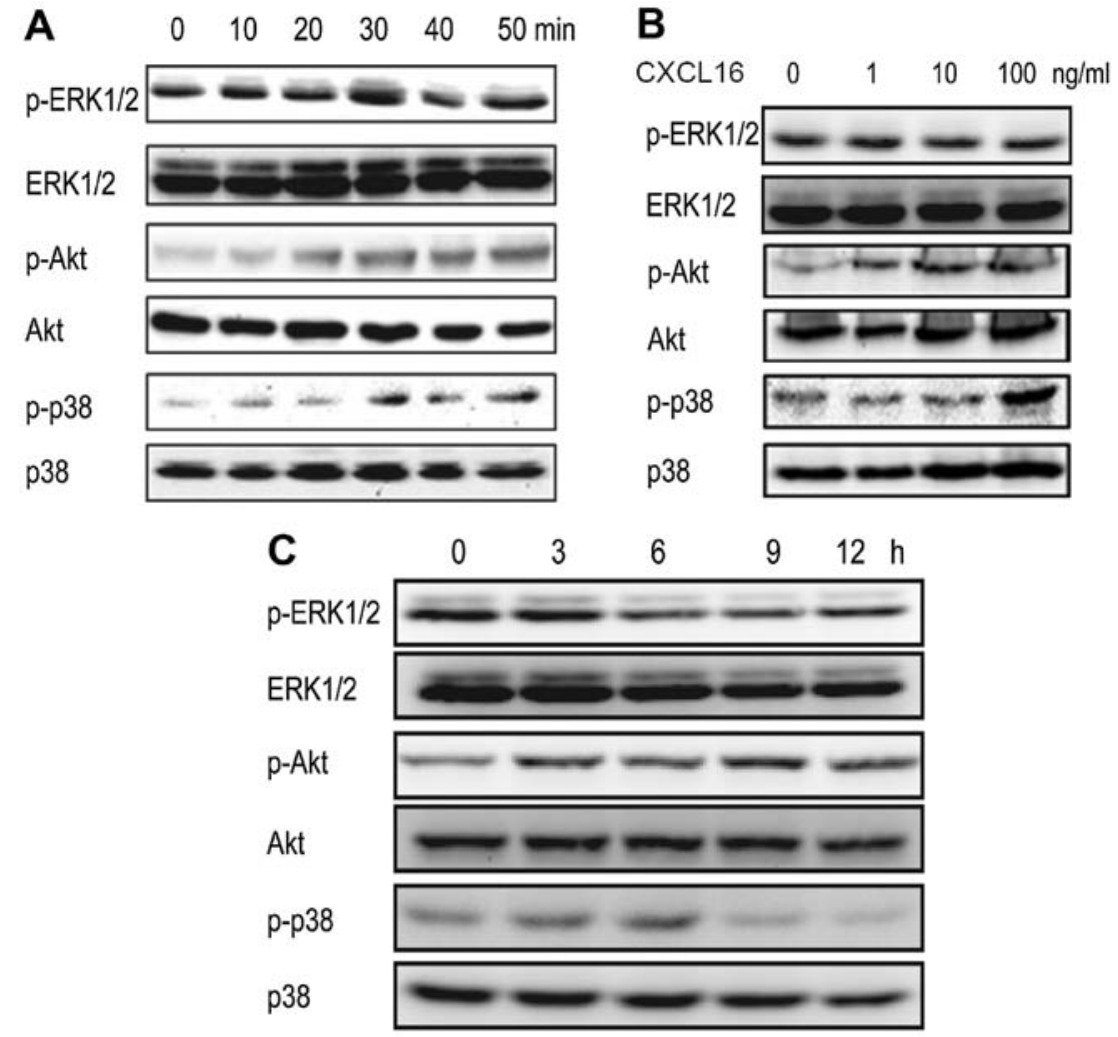

Figure 2. Activation of ERK1/2, Akt and p38 pathways induced by CXCL16. (A) CXCL16 activates ERK1/2, Akt and p38 in a time-dependent manner in HUVECs. HUVECs were treated with $100 \mathrm{ng} / \mathrm{ml}$ of CXCL16 for 0, 10, 20, 30, 40 and $50 \mathrm{~min}$. p-ERK1/2, ERK1/2, p-Akt, Akt, p-p38 and p38 were checked by western blot analyses. (B) CXCL16 activates ERK1/2 and Akt in a dose-dependent manner. HUVECs were treated with 0,1, 10 and $100 \mathrm{ng} / \mathrm{ml}$ of CXCL16 for 30 min. Phosphorylation of ERK1/2, Akt and p38 was analyzed by western blot analyses. (C) Long-term activation of ERK1/2, Akt and p38. HUVECs were treated with $100 \mathrm{ng} / \mathrm{ml}$ of CXCL16 for 0,3,6,9 and $12 \mathrm{~h}$ and followed by western blot analysis.

$3 \mathrm{~h}$ (Fig. 2C); Akt pathway activation reached its maximum level within $1 \mathrm{~h}$ and decreased at $12 \mathrm{~h}$ (Fig. 2C); the highest levels of p-p38 were observed at $6 \mathrm{~h}$ interval (Fig. 2C). The data indicated that CXCL16 activates ERK, p38 and Akt pathways in HUVECs.

Inhibition of ERK, p38 and Akt pathways reduces HUVEC angiogenesis induced by CXCL16. To confirm the involvement of ERK, p38 and Akt pathways in HUVEC-associated angiogenesis induced by CXCL16, we treated HUVECs with $100 \mathrm{ng} / \mathrm{ml}$ CXCL16 and FR180204 (inhibitor of ERK pathway) or SB202190 (inhibitor of p38 pathway) or LY294002 (inhibitor of PI3K/Akt pathway) in proliferation, migration and tube formation assays sequentially. We observed that FR180204, SB202190 and LY294002 markedly attenuated CXCL16-induced HUVEC proliferation (Fig. 3A) and tube formation (Fig. 3F and G), whereas LY294002 decreased HUVEC migration induced by CXCL16 (Fig. 3B and C) or FBS (Fig. 3D and E). It was also observed that SB202190 was effective only in cell migration induced by FBS (Fig. 3D and E). The data revealed the involvement of ERK, p38 and Akt signaling in CXCL16-induced HUVEC proliferation and tube formation and indicated that only Akt pathway was associated with HUVEC migration induced by CXCL16.

Effect of CXCL16 on HIF-1 $\alpha$ expression, and CXCL16stimulated HUVECs to secrete CXCL16 via ERK1/2, p38 and Akt/HIF-1 $\alpha$ pathway. Topotecan is a chemotherapeutic agent. We investigated whether topotecan has an influence in CXCL16-induced angiogenesis. Therefore, we treated HUVECs with different concentrations of CXCL16 and $1 \mu \mathrm{M}$ topotecan. Our findings in tube formation assays revealed that topotecan antagonized the positive effect of CXCL16 on tube formation in vitro (Fig. 4A). Our previous study showed that topotecan inhibits HIF-1 $\alpha$ expression in vitro (26). As shown in Fig. 3A, PX12 (HIF-1 $\alpha$ inhibitor) significantly attenuated HUVEC proliferation induced by CXCL16, indicating the regulation of HIF-1 $\alpha$ by CXCL16. Thus, we further investigated whether CXCL16 influenced HIF-1 $\alpha$ expression with western blotting and RT-PCR assays. Our results showed that CXCL16 increased HIF-1 $\alpha$ protein (Fig. 4B) and mRNA level at $3 \mathrm{~h}$ (Fig. 4D), however, the protein level of HIF-1 $\alpha$ was reduced after $6 \mathrm{~h}$.

Regarding the data of CXCL16 activated ERK1/2, p38 and Akt pathways, we showed these pathways were correlated with HIF-1 $\alpha$ upregulation induced by CXCL16. Upon exposure of HUVECs to FR180204, SB202190, LY294002 and PX12 in the presence of CXCL16 for $6 \mathrm{~h}$, we found that all the inhibitors reduced the improvement in HIF-1 $\alpha$ expression induced by CXCL16 at $6 \mathrm{~h}$ (Fig. 4E). These results implicated that CXCL16 increased HIF-1 $\alpha$ expression through ERK1/2, p38 and Akt pathways under normoxia.

All the results shown above were performed with the exogenous CXCL16 peptide with molecular weight of $10.1 \mathrm{kDa}$. We also investigated whether exogenous CXCL16 affected the expression of endogenous CXCL16 in the same way. 

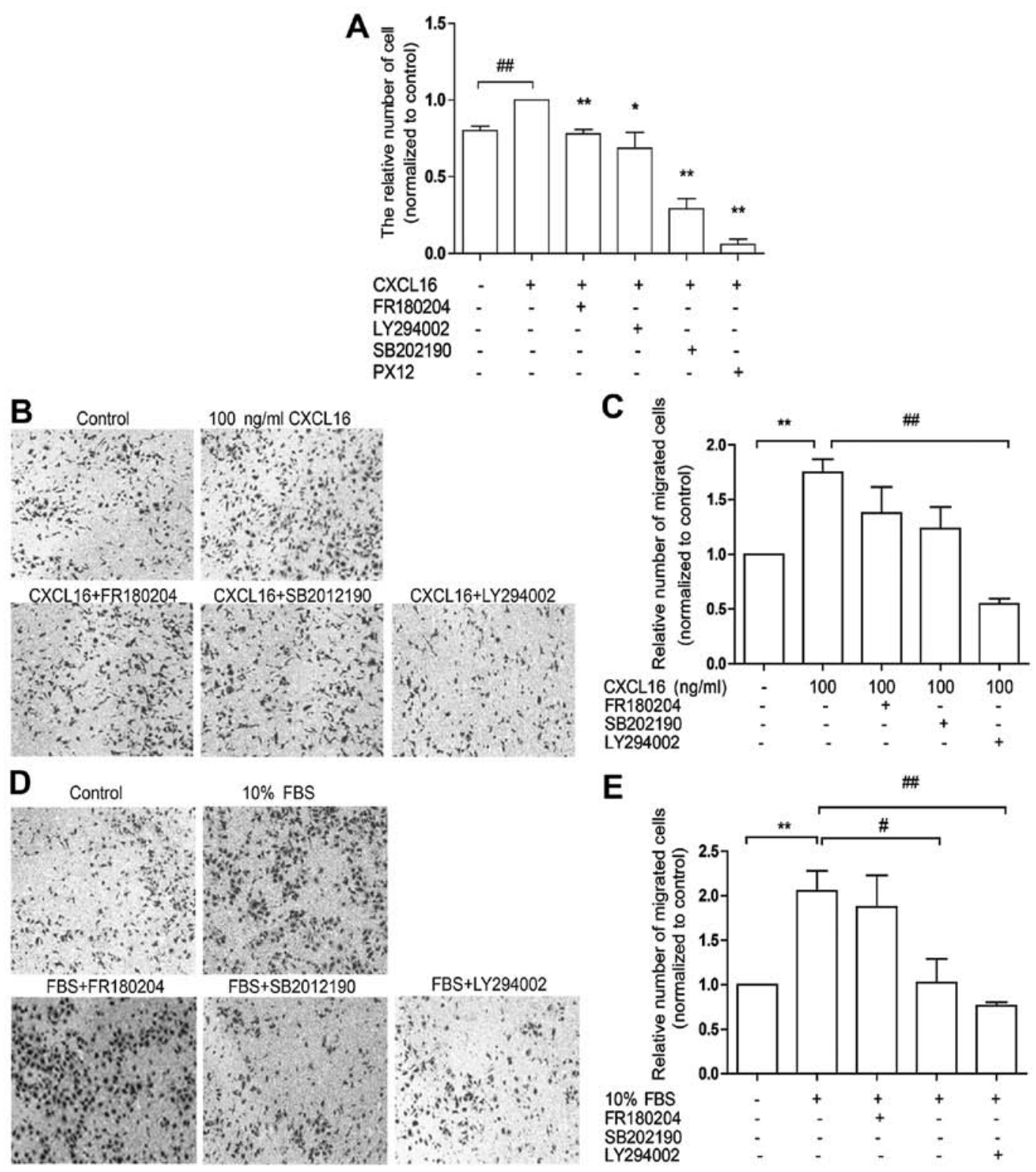

$10 \%$ FBS

E
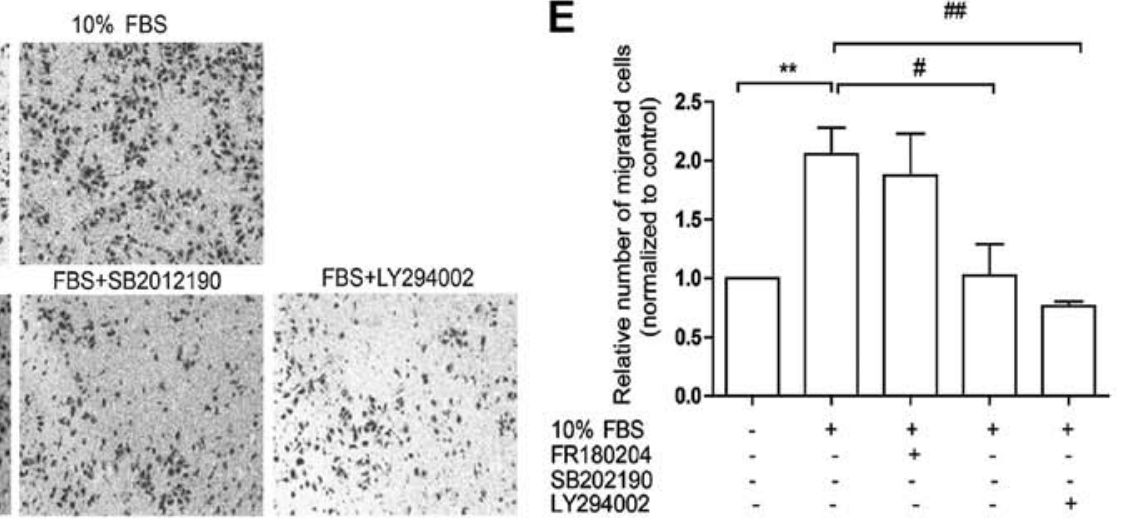

F control
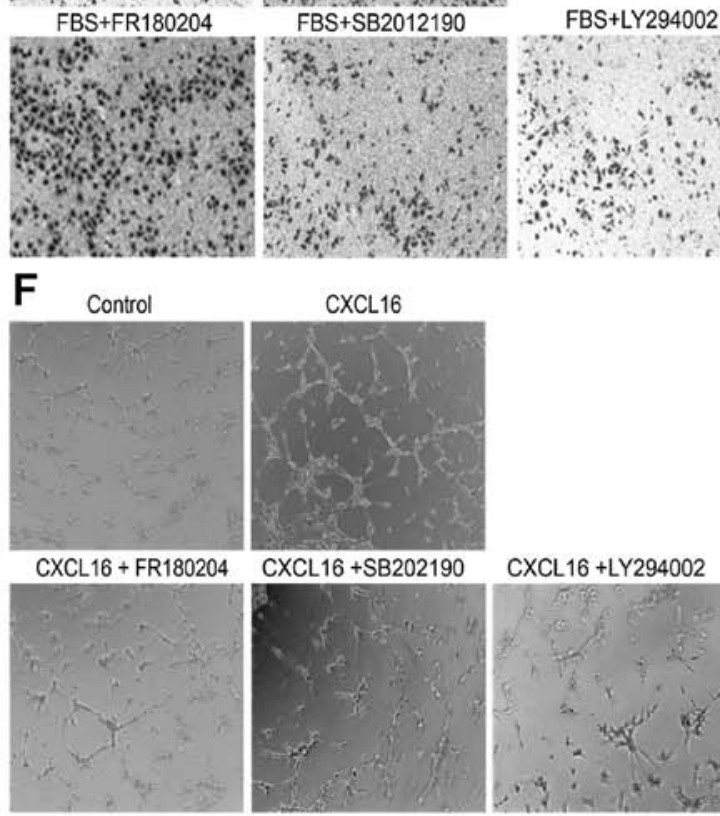

CXCL16+SB202190
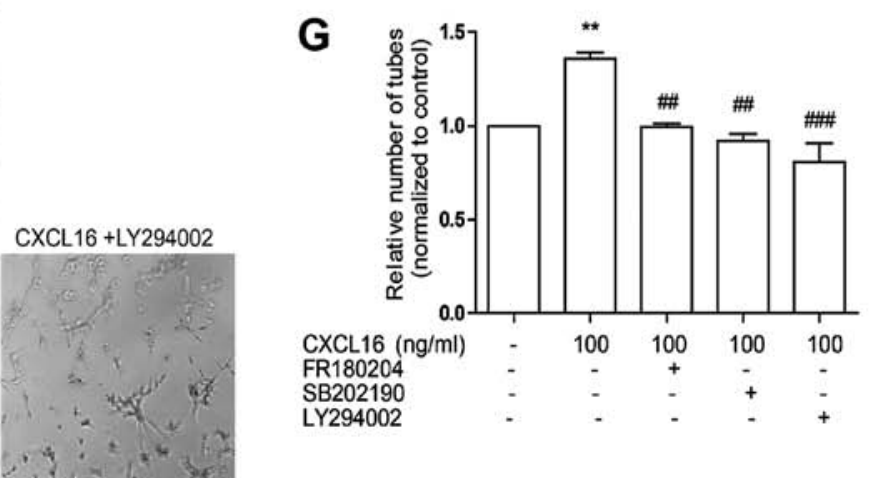

Figure 3. Involvements of ERK1/2, Akt and MAPK p38 pathways in angiogenesis induced by CXCL16. CXCL16 induces HUVECs proliferation (A) and tube formation (F) via ERK, Akt and p38 pathways. HUVECs were treated with $100 \mathrm{ng} / \mathrm{ml}$ of CXCL16 in the presence of $2.5 \mu \mathrm{M}$ FR180204, $5 \mu \mathrm{M}$ SB202190 and $5 \mu \mathrm{M} \mathrm{LY} 294002$ for 48 (A) or $24 \mathrm{~h}$ (F). Cells were also treated with PX12 for $48 \mathrm{~h}$ (A). (B and C) Involvement of MAPK p38 pathway in HUVECs migration induced by CXCL16. (D and E) MAPK p38 and the Akt pathways are related to FBS-induced HUVECs migration. Cells from five fields/group were calculated under a microscope. The relative number of cells (A, B and D) and tubes (F) were normalized to control. * ${ }^{* *}<0.01$, compared with control (PBS); $\mathrm{P}<0.05,{ }^{\# \#} \mathrm{P}<0.01,{ }^{\# \#} \mathrm{P}<0.001$ compared with CXCL16 group.

Therefore, we treated HUVECs with $100 \mathrm{ng} / \mathrm{ml}$ of CXCL16 peptide for 0-12 $\mathrm{h}$, and harvested the supernatant and cells for western blot analysis. Our findings indicated that CXCL16 peptide increased endogenous CXCL16 secretion (Fig. 4B 

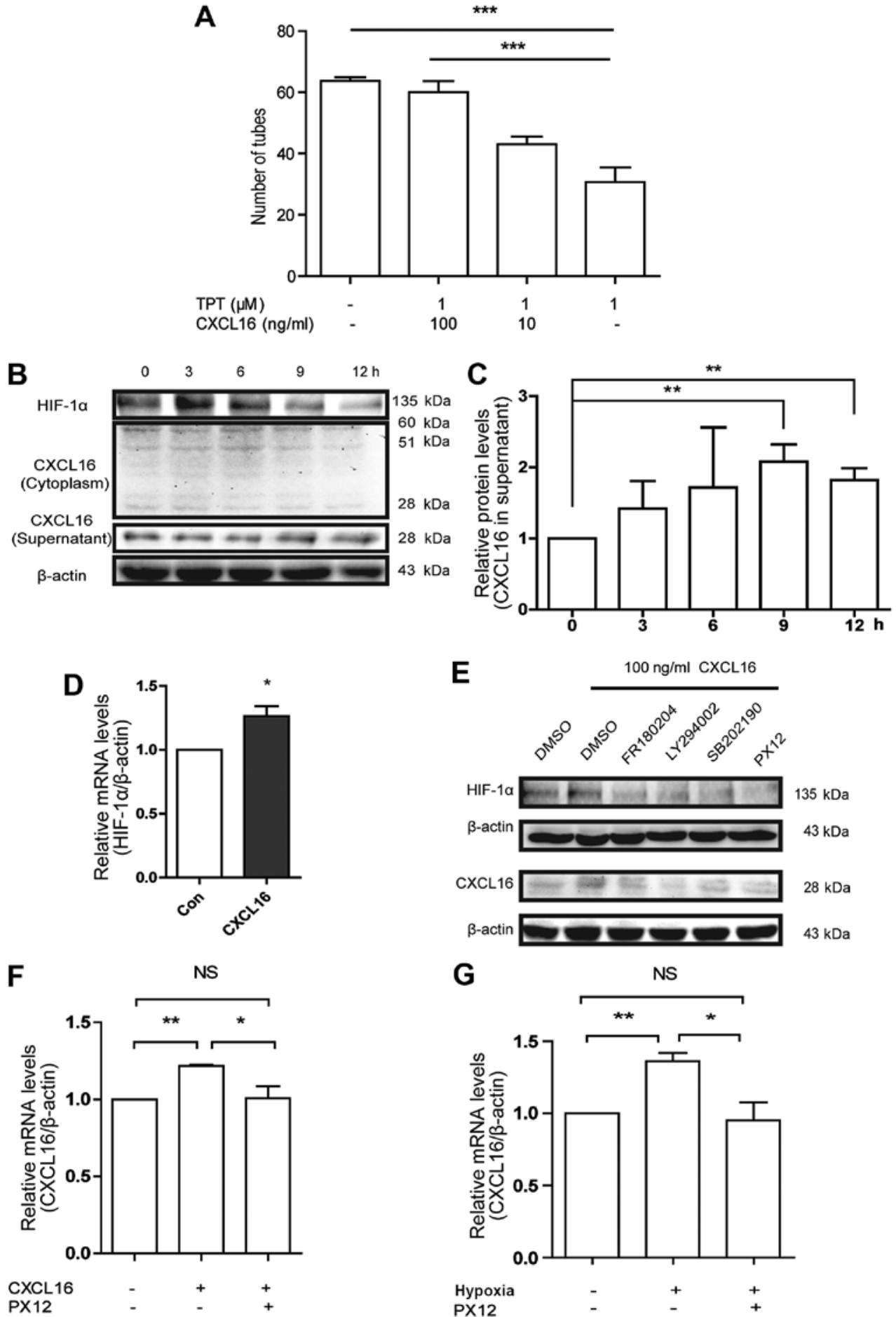

Figure 4. Effects of CXCL16 on HIF-1 $\alpha$ in HUVECs, and CXCL16-induced HUVECs to excrete CXCL16 by upregulating HIF-1 $\alpha$ through ERK, Akt and p38 pathways. (A) Involvement of HIF-1 $\alpha$ in CXCL16 induced tube formation in HUVECs. Cells were treated with $100 \mathrm{ng} / \mathrm{ml}$ CXCL16, or with TPT with different concentrations of CXCL16 (100, 1 and $0 \mathrm{ng} / \mathrm{ml})$ for $6 \mathrm{~h}$. Relative numbers of tubes were normalized to control (PBS). ${ }^{* * *} \mathrm{p}<0.001$, compared with $100 \mathrm{ng} / \mathrm{ml} \mathrm{CXCL16}$ group. (B and C) CXCL16 increases HIF-1 $\alpha$ expression in HUVECs. Cells were treated with $100 \mathrm{ng} / \mathrm{ml}$ of CXCL16 for 0, 3, 6, 9 and $12 \mathrm{~h}$. Total proteins from the cells were examined for HIF-1 $\alpha$ expression by western blot assays. Conditioned medium and cell lysates were collected from HUVECs treated with $100 \mathrm{ng} / \mathrm{ml}$ of CXCL16 for 0,3, 6,9 and $12 \mathrm{~h}$. Proteins were examined for CXCL16 expression in cytoplasm and supernatant with murine anti-CXCL16 antibodies by western blot assays. (D) CXCL16 increases HIF-1 $\alpha$ mRNA in HUVECs. Cells were treated with $100 \mathrm{ng} / \mathrm{ml}$ of CXCL16 for $3 \mathrm{~h}$ and followed by mRNA extraction and subsequent qRT-PCR analysis. The mRNA level was normalized to control group. " $\mathrm{p}<0.05$. (E) Cell lysates were collected from HUVECs treated with $100 \mathrm{ng} / \mathrm{ml}$ of CXCL16 in the presence of inhibitors against ERK, p38, Akt and HIF-1 $\alpha$ for $6 \mathrm{~h}$. HIF-1 $\alpha$ and CXCL16 expressions were analyzed by western blot analyses. (F and G) CXCL16 induces CXCL16 secretion via the regulation of HIF-1 $\alpha$ in HUVECs. PX12 decreased CXCL16 mRNA level after CXCL16 peptide treatment for $6 \mathrm{~h}(\mathrm{~F})$ or hypoxia treatment for $12 \mathrm{~h}(\mathrm{G}) .{ }^{*} \mathrm{P}<0.05,{ }^{* *} \mathrm{P}<0.01,{ }^{* * * *} \mathrm{P}<0.001$.

and C) and mRNA level of CXCL16 at $6 \mathrm{~h}$ (Fig. 4F). These results suggested that CXCL16 is probably self-regulated and modulates angiogenesis in HUVECs.
To determine the pathways involved in CXCL16 secretion, we treated HUVECs with CXCL16 (100 ng/ml) and FR180204, SB202190, LY294002 or PX12, respectively, for $12 \mathrm{~h}$. These 
A

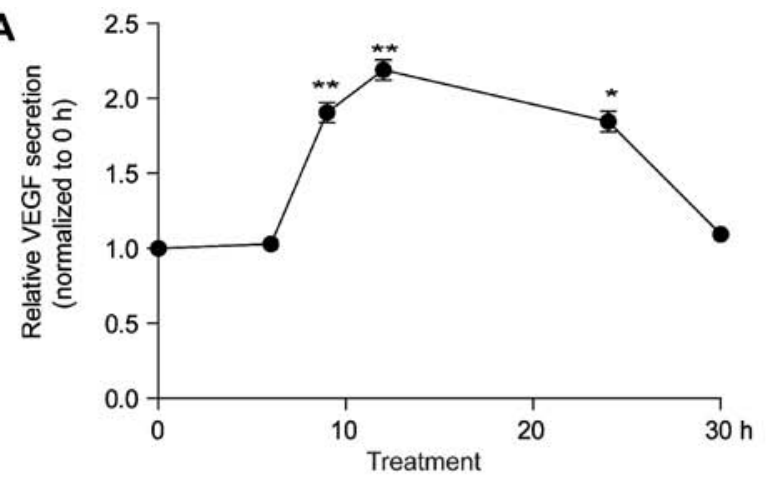

B
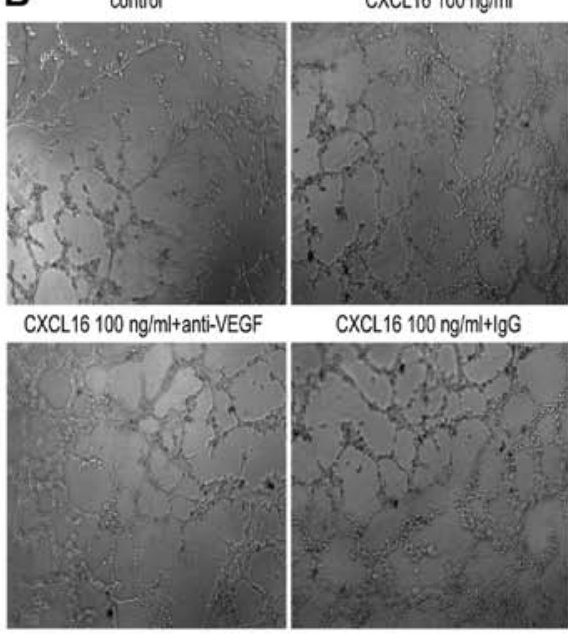

C

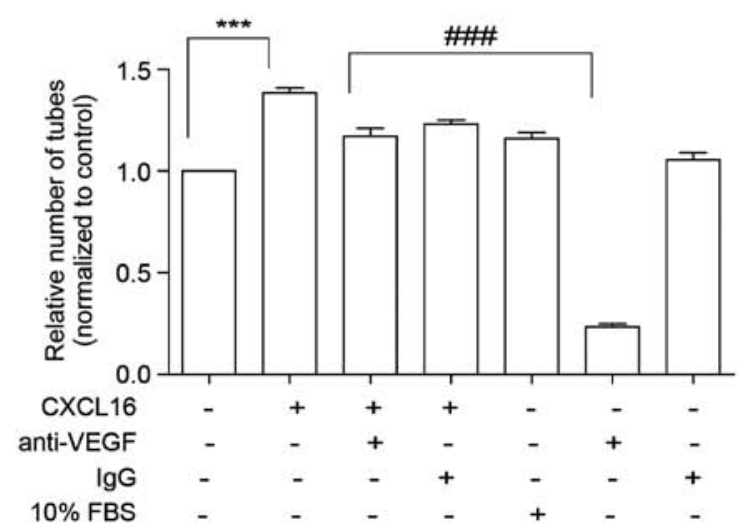

Figure 5. Effects of CXCL16 on tube formation are not due to VEGF secretion in HUVECs. (A) HUVECs were treated with $100 \mathrm{ng} / \mathrm{ml}$ of CXCL16 for 0, 3, $6,9,12,24$ and $30 \mathrm{~h}$. Supernatants were collected and analyzed with VEGF ELISA kit in three repetitive wells. VEGF amount in the supernatants were normalized to control $(0 \mathrm{~h})$ and shown as mean \pm SEM. (B and C) CXCL16 induces HUVEC tube formation in autocrine manner and is not due to VEGF secretion. HUVECs were treated with $100 \mathrm{ng} / \mathrm{ml}$ of CXCL16 and, at the same time anti-VEGF antibody (R\&D Systems) was added for $24 \mathrm{~h}$. Cells from five random fields/group were calculated under a microscope. ${ }^{*} \mathrm{P}<0.05,{ }^{* *} \mathrm{P}<0.01$,

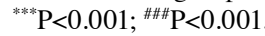

inhibitors reversed the increase of CXCL16 secretion induced by CXCL16 peptide (Fig. 4E). In addition, we found that PX12 significantly reduced mRNA level of CXCL16 induced by CXCL16 peptide (Fig. 4F). These results indicated that CXCL16 regulates its expression by itself via ERK1/2, p38 and Akt pathways and HIF-1 $\alpha$ regulation in HUVECs under normoxia.
To confirm the expression of CXCL16 via HIF-1 $\alpha$, we pre-treated HUVECs with PX12 or DMSO for $1 \mathrm{~h}$, and then incubated HUVECs under hypoxia or normoxia for $6 \mathrm{~h}$; notably we found that hypoxia increased the CXCL16 mRNA level that was previously inhibited by PX12 (Fig. 4G). These findings suggested that CXCL16 induces HUVEC secretion under normoxia via activation of ERK, p38 and Akt signaling and involvement of HIF-1 $\alpha$.

Effects of CXCL16 on tube formation are not due to VEGF secretion in HUVECs. As the secretion of VEGF is partially regulated by HIF-1 $\alpha$ in endothelial cells $(27,28)$, we examined the secretion of VEGF from HUVECs treated with CXCL16. The HUVECs were exposed to CXCL16 $(100 \mathrm{ng} / \mathrm{ml})$ for different time periods $(0,3,6,9,12,24$ and $30 \mathrm{~h})$, followed by the detection of VEGF in the supernatant. ELISA results showed that the amount of VEGF was significantly increased at $9 \mathrm{~h}$, reaching its maximum during $12 \mathrm{~h}$ and normalized at $30 \mathrm{~h}$ of CXCL16 treatment (Fig. 5A). The data indicate that CXCL16 promotes HUVECs to secrete VEGF possibly by regulating HIF-1 $\alpha$ expression.

We have found that CXCL16 can promote HUVECs to secrete VEGF, which can also promote tube formation. So we added CXCL16 $100 \mathrm{ng} / \mathrm{ml}$ and, at the same time we added anti-VEGF antibody (R\&D Systems) to verify whether the effect of CXCL16 on tube formation is due to VEGF secretion in HUVECs or due to some other reason. Notably, we found that the tube formation was reduced to a small extent (Fig. 5B and C). The data indicated that the effect of CXCL16 on tube formation was not due to VEGF secretion in HUVECs.

\section{Discussion}

Recent research has shown that CXCL16 and its receptor play crucial roles in cancer growth and metastasis $(6,15,16)$. Although many studies have confirmed the effect of CXCL16 in tumorigenesis, the effect of CXCL16 on angiogenesis was not clarified. The present study was aimed to investigate the signaling pathways of CXCL16 during angiogenesis. We demonstrated an autocrine signaling of CXCL16 that induced angiogenesis via activating ERK1/2, p38 and Akt pathways and upregulating HIF-1 $\alpha$ expression in HUVECs.

Akt phosphorylation is crucial in angiogenesis both in vitro and in vivo $(20,29,30)$, and ERK and p38 pathways were also considered to be associated with angiogenesis $(21,31,32)$. It has been found that CXCL16 activates Elt in HUVECs within $30 \mathrm{~min}$ (17). Consistent with these findings, activations of Akt, ERK and p38 by CXCL16 was also observed to be started within $30 \mathrm{~min}$ in HUVECs. However, the activation of ERK, Akt and p38 was decreased after $6 \mathrm{~h}$, which could be due to the desensitization of CXCR6 after prolonged exposure to CXCL16. By treating HUVECs with FR180204 (inhibitor of ERK pathway), SB202190 (p-p38 inhibitor) and LY294002 (p-Akt inhibitor), we confirmed the involvement of ERK, p38 and Akt pathways in the angiogenesis induced by CXCL16 in HUVECs.

HIF-1 $\alpha$, a transcription factor is usually found at low oxygen conditions and mediates cellular responses to hypoxia. Previous studies have suggested that cytokines and growth 
factors, such as epidermal growth factor (33), insulin and interleukin-1 $\beta(34,35)$ induce HIF-1 $\alpha$ expression under normoxia. In the present study, we found that HIF-1 $\alpha$ was upregulated by CXCL16 at both protein and mRNA levels within $6 \mathrm{~h}$ under normoxia. However, at normoxia, HIF1- $\alpha$ immediately degrades by cell type-specific regulation of von Hippel-Lindau tumor-suppressor protein (36). The Akt pathway is involved in the stabilization of HIF-1 $\alpha$ under normoxia (37) and regulation of HIF-1 $\alpha$ expression. ERK and p38 pathways are likely regulating HIF- $1 \alpha$ expression as well $(38,39)$. Consistent with these observations, our data showed that SB202190 (p-p38 inhibitor) and LY294002 (p-Akt inhibitor) suppressed HIF-1 $\alpha$ expression induced by CXCL16.

HIF-1 $\alpha$ induces the expression of VEGF and CXCL12 in endothelial cells $(38,39)$ under normoxia. In addition, CXCL16 improves secretion of VEGF in prostate cancer cells (15). Our data showed that CXCL16 induced HUVECs to secrete VEGF which reached the maximum level within $9 \mathrm{~h}$ under normoxia.

CXCL16 expression in HUVECs was measured. Since the CXCL16, used for treatment, was an exogenous polypeptide with a small molecular weight $(10.1 \mathrm{kDa})$, we were able to distinguish endogenous soluble CXCL16 (30 kDa) from the peptide in western blotting and RT-PCR assays. We found that CXCL16 peptide improved the secretion of endogenous soluble CXCL16 from HUVECs. However, SB202190, FR180204 and LY294002 inhibited the secretion suggesting the involvement of ERK, p38 and Akt pathways in CXCL16 secretion induced by CXCL16 in HUVECs. Furthermore, we found that hypoxia induced CXCL16 mRNA was increased which was resisted by the HIF-1 $\alpha$ pathway inhibitor PX12. It can be due to high level of HIF-1 $\alpha$ induced by CXCL16. The soluble form of CXCL16 was kept in supernatant for $12 \mathrm{~h}$, but HIF-1 $\alpha$, potential upstream of CXCL16, was reduced after treatment with CXCL16 for $6 \mathrm{~h}$, which may be due to the lower level of CXCR6 or CXCR6 desensitization. Thus, our data indicated that exogenous CXCL16 activated ERK, p38, and Akt/HIF-1 $\alpha$ pathway to induce CXCL16 secretion in HUVECs.

In solid tumor, cancer cells excreted CXCL16 to promote angiogenesis, and endothelial cells excreted VEGF under high level of CXCL16. However, CXCL16 exhibit a dual effect in atherosclerotic lesions; CXCL16 not only promotes endothelial cell survival but also guides the migration of macrophages into inflamed tissues, thus resulting in more serious inflammation.

In conclusion, the present study exhibited a novel signaling pathway of CXCL16 in HUVEC angiogenesis. CXCL16 promoted angiogenesis in autocrine signaling in HUVECs under normoxia, involving activation of ERK1/2, Akt and p38 pathways and subsequent upregulation of HIF-1 $\alpha$. Moreover, CXCL16 increased VEGF secretion in HUVECs which is most probably via the regulation of HIF-1 $\alpha$.

\section{Acknowledgements}

The present study was financially supported by the 'National Natural Science Funds' Project nos. 81102853 and 81071841, and the 2011 Program for Excellent Scientific and Technological Innovation Team of Jiangsu Higher Education. For this sponsorship we are highly thankful to both organizations.

\section{References}

1. Matloubian M, David A, Engel S, Ryan JE and Cyster JG: A transmembrane CXC chemokine is a ligand for HIV-coreceptor Bonzo. Nat Immunol 1: 298-304, 2000.

2. Shimaoka T, Kume N, Minami M, Hayashida K, Kataoka H, Kita $\mathrm{T}$ and Yonehara S: Molecular cloning of a novel scavenger receptor for oxidized low density lipoprotein, SR-PSOX, on macrophages. J Biol Chem 275: 40663-40666, 2000.

3. van der Voort R, van Lieshout AW, Toonen LW, Slöetjes AW, Van Den Berg WB, Figdor CG, Radstake TR and Adema GJ: Elevated CXCL16 expression by synovial macrophages recruits memory T cells into rheumatoid joints. Arthritis Rheum 52: 1381-1391, 2005.

4. Shimaoka T, Nakayama T, Kume N, Takahashi S, Yamaguchi J, Minami M, Hayashida K, Kita T, Ohsumi J, Yoshie O, et al: Cutting edge: SR-PSOX/CXC chemokine ligand 16 mediates bacterial phagocytosis by APCs through its chemokine domain. J Immunol 171: 1647-1651, 2003.

5. Heydtmann M, Lalor PF, Eksteen JA, Hubscher SG, Briskin M and Adams DH: CXC chemokine ligand 16 promotes integrin-mediated adhesion of liver-infiltrating lymphocytes to cholangiocytes and hepatocytes within the inflamed human liver. J Immunol 174: 1055-1062, 2005.

6. Gao Q, Zhao YJ, Wang XY, Qiu SJ, Shi YH, Sun J, Yi Y, Shi JY, Shi GM, Ding ZB, et al: CXCR6 upregulation contributes to a proinflammatory tumor microenvironment that drives metastasis and poor patient outcomes in hepatocellular carcinoma. Cancer Res 72: 3546-3556, 2012.

7. Sung SY, Hsieh CL, Law A, Zhau HE, Pathak S, Multani AS, Lim S, Coleman IM, Wu LC, Figg WD, et al: Coevolution of prostate cancer and bone stroma in three-dimensional coculture: Implications for cancer growth and metastasis. Cancer Res 68: 9996-10003, 2008.

8. Hojo S, Koizumi K, Tsuneyama K, Arita Y, Cui Z, Shinohara K, Minami T, Hashimoto I, Nakayama T, Sakurai H, et al: High-level expression of chemokine CXCL16 by tumor cells correlates with a good prognosis and increased tumor-infiltrating lymphocytes in colorectal cancer. Cancer Res 67: 4725-4731, 2007.

9. Shimaoka T, Nakayama T, Fukumoto N, Kume N, Takahashi S, Yamaguchi J, Minami M, Hayashida K, Kita T, Ohsumi J, et al: Cell surface-anchored SR-PSOX/CXC chemokine ligand 16 mediates firm adhesion of CXC chemokine receptor 6-expressing cells. J Leukoc Biol 75: 267-274, 2004.

10. Gough PJ, Garton KJ, Wille PT, Rychlewski M, Dempsey PJ and Raines EW: A disintegrin and metalloproteinase 10-mediated cleavage and shedding regulates the cell surface expression of CXC chemokine ligand 16. J Immunol 172: 3678-3685, 2004.

11. Abel S, Hundhausen C, Mentlein R, Schulte A, Berkhout TA, Broadway N, Hartmann D, Sedlacek R, Dietrich S, Muetze B, et al: The transmembrane CXC-chemokine ligand 16 is induced by IFN-gamma and TNF-alpha and shed by the activity of the disintegrin-like metalloproteinase ADAM10. J Immunol 172: 6362-6372, 2004.

12. Lehrke M, Konrad A, Schachinger V, Tillack C, Seibold F, Stark R, Parhofer IG and Broedl UC: CXCL16 is a surrogate marker of inflammatory bowel disease. Scand J Gastroenterol 43: 283-288, 2008.

13. Ruth JH, Haas CS, Park CC, Amin MA, Martinez RJ, Haines GK, Shahrara S, Campbell PL and Koch AE: CXCL16-mediated cell recruitment to rheumatoid arthritis synovial tissue and murine lymph nodes is dependent upon the MAPK pathway. Arthritis Rheum 54: 765-778, 2006.

14. Postea O, Koenen RR, Hristov M, Weber C and Ludwig A: Homocysteine up-regulates vascular transmembrane chemokine CXCL16 and induces CXCR6 ${ }^{+}$lymphocyte recruitment in vitro and in vivo. J Cell Mol Med 12: 1700-1709, 2008.

15. Wang J, Lu Y, Koch AE, Zhang J and Taichman RS: CXCR6 induces prostate cancer progression by the AKT/mammalian target of rapamycin signaling pathway. Cancer Res 68: 10367-10376, 2008.

16. Lin S, Sun L, Hu J, Wan S, Zhao R, Yuan S and Zhang L: Chemokine C-X-C motif receptor 6 contributes to cell migration during hypoxia. Cancer Lett 279: 108-117, 2009.

17. Zhuge X, Murayama T, Arai H, Yamauchi R, Tanaka M, Shimaoka T, Yonehara S, Kume N, Yokode M and Kita T: CXCL16 is a novel angiogenic factor for human umbilical vein endothelial cells. Biochem Biophys Res Commun 331: 1295-1300, 2005. 
18. Chandrasekar B, Bysani S and Mummidi S: CXCL16 signals via Gi, phosphatidylinositol 3-kinase, Akt, I kappa B kinase, and nuclear factor-kappa B and induces cell-cell adhesion and aortic smooth muscle cell proliferation. J Biol Chem 279: 3188-3196, 2004.

19. Kwon KH, Ohigashi H and Murakami A: Dextran sulfate sodium enhances interleukin-1 beta release via activation of p38 MAPK and ERK1/2 pathways in murine peritoneal macrophages. Life Sci 81: 362-371, 2007

20. Jiang BH, Zheng JZ, Aoki M and Vogt PK: Phosphatidylinositol 3-kinase signaling mediates angiogenesis and expression of vascular endothelial growth factor in endothelial cells. Proc Nat Acad Sci USA 97: 1749-1753, 2000.

21. Binion DG, Otterson MF and Rafiee P: Curcumin inhibits VEGF-mediated angiogenesis in human intestinal microvascular endothelial cells through COX-2 and MAPK inhibition. Gut 57: 1509-1517, 2008

22. Zhu WH, Han J and Nicosia RF: Requisite role of p38 MAPK in mural cell recruitment during angiogenesis in the rat aorta model. J Vasc Res 40: 140-148, 2003.

23. Zhao R, Sun L, Lin S, Bai X, Yu B, Yuan S, and Zhang L: The saponin monomer of dwarf lilyturf tuber, DT-13, inhibits angiogenesis under hypoxia and normoxia via multi-targeting activity. Oncol Rep 29: 1379-1386, 2013.

24. Chi JT, Wang Z, Nuyten DS, Rodriguez EH, Schaner ME, Salim A, Wang Y, Kristensen GB, Helland Å, Børresen-Dale AL, et al: Gene expression programs in response to hypoxia: Cell type specificity and prognostic significance in human cancers. PLoS Med 3: e47, 2006

25. Petering H, Kluthe C, Dulkys Y, Kiehl P, Ponath PD, Kapp A and Elsner J: Characterization of the CC chemokine receptor 3 on human keratinocytes. J Invest Dermatol 116: 549-555, 2001

26. Zhou L, Sun L, Lin S, Fang D, Zhao R, Zhu J, Liu J, Chen L, Shi W, Yuan S, et al: Inhibition of angiogenic activity of hypoxic fibroblast cell line MRC-5 in vitro by topotecan. Med Oncol 28: 653-659, 2011

27. Kim HG, Hwang YP and Jeong HG: Metallothionein-III induces HIF-1alpha-mediated VEGF expression in brain endothelial cells. Biochem Biophys Res Commun 369: 666-671, 2008.

28. Ahluwalia A and Tarnawski AS: Critical role of hypoxia sensor HIF-1 $\alpha$ in VEGF gene activation. Implications for angiogenesis and tissue injury healing. Curr Med Chem 19: 90-97, 2012.

29. Zubilewicz A, Hecquet C, Jeanny JC, Soubrane G, Courtois Y and Mascarelli F: Two distinct signalling pathways are involved in FGF2-stimulated proliferation of choriocapillary endothelial cells: A comparative study with VEGF. Oncogene 20: 1403-1413, 2001.
30. Wang HQ, Bai L, Shen BR, Yan ZQ and Jiang ZL: Coculture with endothelial cells enhances vascular smooth muscle cell adhesion and spreading via activation of beta1-integrin and phosphatidylinositol 3-kinase/Akt. Eur J Cell Biol 86: 51-62, 2007.

31. Gee E, Milkiewicz M and Haas TL: p38 MAPK activity is stimulated by vascular endothelial growth factor receptor 2 activation and is essential for shear stress-induced angiogenesis. J Cell Physiol 222: 120-126, 2010.

32. Mavria G, Vercoulen Y, Yeo M, Paterson H, Karasarides M, Marais R, Bird D and Marshall CJ: ERK-MAPK signaling opposes Rho-kinase to promote endothelial cell survival and sprouting during angiogenesis. Cancer Cell 9: 33-44, 2006.

33. Zhong H, Chiles K, Feldser D, Laughner E, Hanrahan C, Georgescu MM, Simons JW and Semenza GL: Modulation of hypoxia-inducible factor 1alpha expression by the epidermal growth factor/phosphatidylinositol 3-kinase/PTEN/AKT/FRAP pathway in human prostate cancer cells: Implications for tumor angiogenesis and therapeutics. Cancer Res 60: 1541-1545, 2000.

34. Treins C, Giorgetti-Peraldi S, Murdaca J, Semenza GL and Van Obberghen E: Insulin stimulates hypoxia-inducible factor 1 through a phosphatidylinositol 3-kinase/target of rapamycin-dependent signaling pathway. J Biol Chem 277: 27975-27981, 2002.

35. Stiehl DP, Jelkmann W, Wenger RH and Hellwig-Burgel T: Normoxic induction of the hypoxia-inducible factor 1alpha by insulin and interleukin-1beta involves the phosphatidylinositol 3-kinase pathway. FEBS Lett 512: 157-162, 2002.

36. Zheng X, Ruas JL, Cao R, Salomons FA, Cao Y, Poellinger L and Pereira T: Cell-type-specific regulation of degradation of hypoxia-inducible factor 1 alpha: Role of subcellular compartmentalization. Mol Cell Biol 26: 4628-4641, 2006.

37. Lai VK, Afzal MR, Ashraf M, Jiang S and Haider HK: Non-hypoxic stabilization of HIF-Ialpha during coordinated interaction between Akt and angiopoietin-1 enhances endothelial commitment of bone marrow stem cells. J Mol Med 90: 719-730, 2012.

38. Hur E, Chang KY, Lee E, Lee SK and Park H: Mitogen-activated protein kinase kinase inhibitor PD98059 blocks the transactivation but not the stabilization or DNA binding ability of hypoxia-inducible factor-1alpha. Mol Pharmacol 59: 1216-1224, 2001.

39. Roos TU, Heiss EH, Schwaiberger AV, Schachner D, Sroka IM, Oberan T, Vollmar AM and Dirsch VM: Caffeic acid phenethyl ester inhibits PDGF-induced proliferation of vascular smooth muscle cells via activation of p38 MAPK, HIF-1alpha, and heme oxygenase-1. J Nat Prod 74: 352-356, 2011. 